\title{
TEMPERATURE EFFECTS ON BOND BETWEEN CONCRETE AND REINFORCING STEEL
}

Éva Lublóy

Balázs L. György

УДК: 624.078.4:536.4

DOI:10.14415/zbornikGFS26.03

Summary: Bond behaviour between concrete and reinforcing bars was observed under elevated temperatures. Five different concrete compositions were used. Hundred five pull-out specimens ( $0120 \mathrm{~mm}, 100 \mathrm{~mm})$ were prepared. After removing the specimens from the formwork, they were stored in water for seven days then kept at laboratory conditions until testing. The specimens were 28 days old by testing. After heating up the specimens, they were kept for two hours at these maximum temperatures $\left(20^{\circ} \mathrm{C}, 150^{\circ} \mathrm{C}\right.$, $300{ }^{\circ} \mathrm{C}, 400{ }^{\circ} \mathrm{C}, 500{ }^{\circ} \mathrm{C}, 800{ }^{\circ} \mathrm{C}$ ). Specimens were then cooled down in laboratory conditions. Finally the specimens were tested at room temperature. In order to check the compressive strength standard cubes were cast, cured, and heat treated, then tested to compressive strength. The results showed reduction in residual compressive strength and considerable changes in steel-concrete bond under high temperatures. Based on test results, a proposal is presented for the modification of MC2010 bond-ship formula in order to consider temperature effect.

Keywords: Concrete, reinforcement, bond, elevated temperature

\section{INTRODUCTION}

In some areas of bond behaviour (like fatigue and especially high temperatures) limited information is available. The main reasons are complexity of the experiments and the high cost.

During the exposure to high temperatures, concrete undergoes changes in its chemical composition, physical structure and water content. These changes primarily occur in the hardened cement paste. The resulting physical changes and chemical decomposition of major concrete constituents are demonstrated by e. g. cracks, explosive spalling or both $[1,2,3,4,5]$.

Investigations on the bond strength between concrete and reinforcing steel at room temperature have been carried out over many years however, only few experiments have been carried out to study the effects of high temperature on the bond characteristics. Bažant and Kaplan [5] concluded their results (that is also presented in Figure 1):

Bond strength reduces as temperature increases, and the reduction rate is greater compared that of concrete strength. The percentage reduction of bond strength for ribbed bars at elevated temperatures is less than that for plain round steel bars. 
Differences in the diameters of plain bars and deformed bars had little effect on the strength reduction of bond.

The experimental procedure influences the results of bond tests at high temperatures.

The type of aggregate in the concrete affects the bond strength at elevated temperatures.

The smaller the concrete cover, the greater is the reduction in bond strength.

Post heating behaviour of the concrete to steel bond has been investigated over the past 50 years using two types of bond test specimens, specified in ASTM (Annual Book of ASTM Standards, 1993) and RILEM (Bond test for reinforcement bond steel: 2- pull-out test, 1983) test methods $[6,7]$.

The different studies showed significant effects of steel rebar surface characteristics, concrete confinement, concrete basic properties (w/c ratio, cement and aggregate type, additives), maturity and relative humidity, and testing conditions (heating and cooling duration and rate, and testing while hot or cold on concrete to steel bond behaviour under wide range of high temperature) $[5,8,9,10]$.

Due to the complexity of bond characterisation at elevated temperatures, as first order approximation, simplified bi-linear and tri-linear models, as shown in Figure 1 are proposed herein to calculate the bond strengths of deformed and smooth bars at elevated temperatures, respectively.

Based on results by Bazant and Kaplan [5] Huang [11] proposed the following equations:

$$
\begin{array}{cc}
\tau_{\max , T}=\tau_{\max , 20}\left(1.0-\frac{0.22}{76 n}(T-20)\right) & \text { for } 20{ }^{\circ} \mathrm{C} \leq \mathrm{T} \leq 380{ }^{\circ} \mathrm{C} \\
\tau_{\max , T}=\tau_{\max , 20}\left(0.78-\frac{0.75}{270}(T-380)\right) & \text { for } 380{ }^{\circ} \mathrm{C}<\mathrm{T} \leq 650{ }^{\circ} \mathrm{C} \\
\tau_{\max , T}=0.03 \tau_{\max , 20} \quad \text { for } 650{ }^{\circ} \mathrm{C}<\mathrm{T}
\end{array}
$$

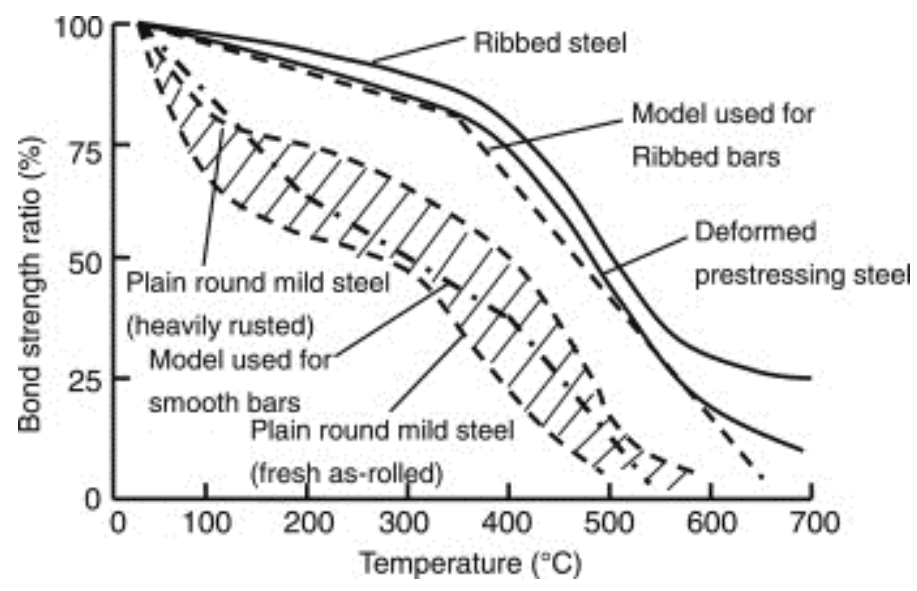

Figure 1: Degradation of bond strength between concrete and reinforcing steel [5] 


\section{EXPERIMENTAL STUDY}

We carried out an experimental study to analyze the bond characteristics after high temperatures. Test variables were:

- maximal temperature $\left(20^{\circ} \mathrm{C}, 50^{\circ} \mathrm{C}, 150^{\circ} \mathrm{C}, 300^{\circ} \mathrm{C}, 400^{\circ} \mathrm{C}, 500^{\circ} \mathrm{C}, 600^{\circ} \mathrm{C}, 800^{\circ} \mathrm{C}\right)$

- type of aggregate (quartz gravel, expanded clay)

- type of fibres (polypropylene fibers, hocked-end steel fibers).

The water cement ratio was constant: $\mathrm{w} / \mathrm{c}=0.43$. The amount of cement, water, aggregate, fibres and plasticizer are given in Table 1 . The consistency of concrete was measured by flow table tests and resulted 450 to $500 \mathrm{~mm}$.

Table 1 Experimental concrete mixes (* polypropylene fibers, **hocked-end steel fibers)

\begin{tabular}{|l|l|l|l|l|l|l|}
\hline & Mix 0 & Mix 1 & Mix 2 & Mix 3 & Mix 4 & Mix 5 \\
\hline cement $\left(\mathrm{kg} / \mathrm{m}^{3}\right)$ & 350 & 350 & 350 & 386 & 386 & 350 \\
\hline water $\left(\mathrm{kg} / \mathrm{m}^{3}\right)$ & 151 & 151 & 151 & 181 & 181 & 151 \\
\hline $\begin{array}{c}\text { aggregate }\left(\mathrm{kg} / \mathrm{m}^{3}\right) \\
0-4 \mathrm{~mm}\end{array}$ & $\begin{array}{l}912 \\
\text { quartz } \\
\text { sand }\end{array}$ & $\begin{array}{l}912 \\
\text { quartz } \\
\text { sand }\end{array}$ & $\begin{array}{l}912 \\
\text { quartz sand }\end{array}$ & $\begin{array}{l}1024 \\
\text { quartz sand }\end{array}$ & $\begin{array}{l}1015 \\
\text { quartz } \\
\text { sand }\end{array}$ & $\begin{array}{l}912 \\
\text { quartz } \\
\text { sand }\end{array}$ \\
\hline $\begin{array}{l}\text { aggregate }\left(\mathrm{kg} / \mathrm{m}^{3}\right) \\
4-8 \mathrm{~mm}\end{array}$ & $\begin{array}{l}485 \\
\text { quartz } \\
\text { gravel }\end{array}$ & $\begin{array}{l}485 \\
\text { quartz } \\
\text { gravel }\end{array}$ & $\begin{array}{l}485 \\
\text { expanded } \\
\text { clay }\end{array}$ & $\begin{array}{l}302 \\
\text { expanded } \\
\text { clay }\end{array}$ & $\begin{array}{l}390 \\
\text { quartz } \\
\text { gravel }\end{array}$ & $\begin{array}{l}485 \\
\text { quartz } \\
\text { gravel }\end{array}$ \\
\hline $\begin{array}{l}\text { aggregate }\left(\mathrm{kg} / \mathrm{m}^{3}\right) \\
8-16 \mathrm{~mm}\end{array}$ & 544 & 544 & 544 & - & - & 544 \\
\hline plasticizer kg/m $\left.\mathrm{m}^{3}\right)$ & 1.4 & 1.4 & 1.4 & 5 & 5 & 1.4 \\
\hline fibres $\left(\mathrm{kg} / \mathrm{m}^{3}\right)$ & - & $1^{*}$ & $1^{*}$ & - & - & $35^{* *}$ \\
\hline
\end{tabular}

By the preparation of specimens special casting forms were used (Figure 2). The pull-out specimens had a diameter of $120 \mathrm{~mm}$ and height of $100 \mathrm{~mm}$. Details of pull-out specimens are presented in Figure 3. Slip was measured with two LVDT's at the unloaded side (Figure 3).
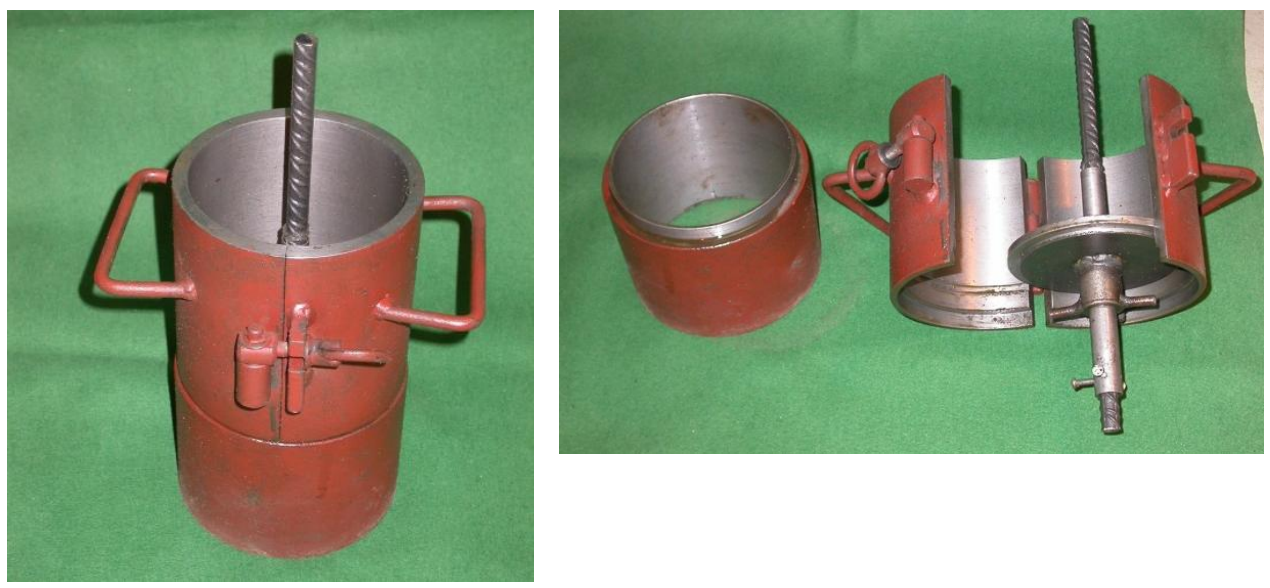

Figure 2: The casting forms to the measurements of bond strength 

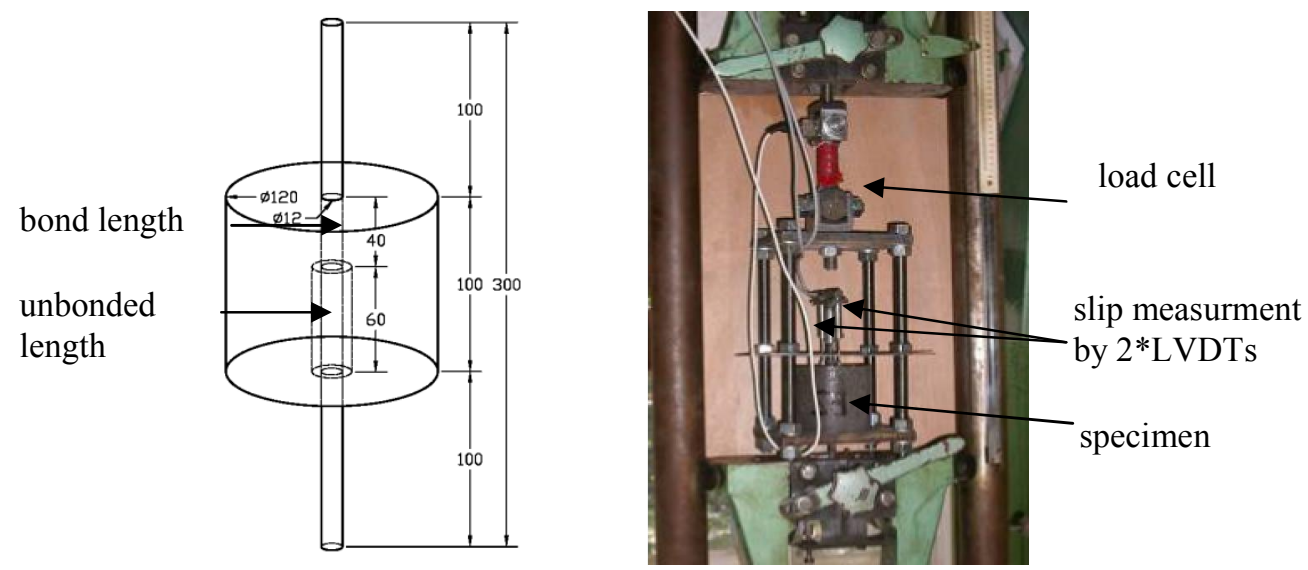
a) Specimen
Figure 3: Pull-out tests

\section{TEST RESULTS}

\subsection{Compressive strength}

The compressive strength was measured after the heating process on concrete cubes of $150 \mathrm{~mm}$ sides. Figure 4 indicates the measured relative residual compressive strength values of concrete as a function of maximal temperatures up to $800{ }^{\circ} \mathrm{C}$.

1. Most considerable reduction of compressive strength took place between $400{ }^{\circ} \mathrm{C}$ and $800{ }^{\circ} \mathrm{C}$ in all cases within our temperature range.

2. The residual compressive strength values at the maximal temperature of $800{ }^{\circ} \mathrm{C}$ were between $20 \%$ to $30 \%$ of the strength at $20{ }^{\circ} \mathrm{C}$ for concretes with polypropylene fibers (Mix 1) and for concrete without fibres (Mix 0). Our test results indicated the advantageous influence of polymeric fibres in concrete subjected to high temperatures.

3. The residual compressive strength values of quartz gravel aggregate at the maximal temperature of $800{ }^{\circ} \mathrm{C}$ was $20 \%$ of the strength at $20^{\circ} \mathrm{C}$ for concretes with steel fibers. Between $50{ }^{\circ} \mathrm{C}$ and $400{ }^{\circ} \mathrm{C}$ the highest strength reductions were in case of specimens with steel fibers. That can be explained by the similar forms of fibers.

4. The relative residual compressive strength of lightweight aggregate concrete with expanded clay (Mix 2 and Mix 3) was higher after heating the specimens up to $400{ }^{\circ} \mathrm{C}$ and then cooled down to room temperature as in the case of concrete with quartz gravel aggregate. The relative residual compressive strength values were lower in case of concrete with quartz gravel aggregate by 10 to $20 \%$. 


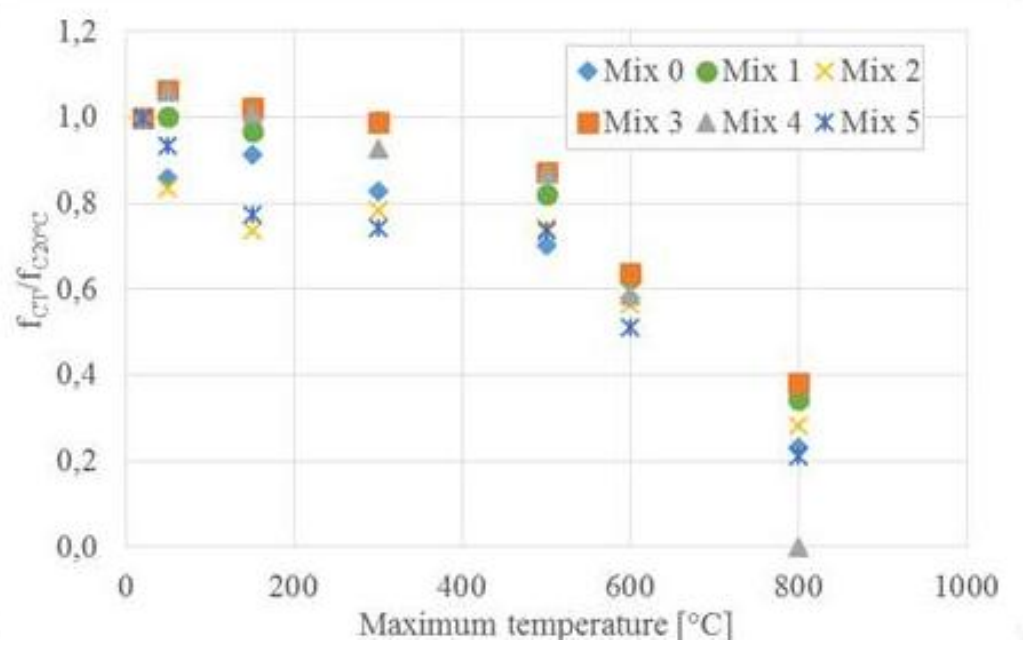

Figure 4: Relative residual compressive strength (every point gives the average of 3 measurements)

\subsection{Bond strength}

Figure 5 indicates the measured relative residual bond strength values of concrete as a function of maximal temperatures up to $800{ }^{\circ} \mathrm{C}$. Pull-out test were carried out at room temperature after heating and cooling the specimens. The following conclusions can be drawn:

1. The relative bond strength reduction was higher than the relative compressive strength reduction in all cases.

2. Most considerable reduction of bond strength took place between $400{ }^{\circ} \mathrm{C}$ and $500{ }^{\circ} \mathrm{C}$. This reduction can be explained by the decomposition of portlandite at $450{ }^{\circ} \mathrm{C}$.

3. The relative bond strength of lightweight concrete with expanded clay (Mix 2 and Mix 3) was higher to $400{ }^{\circ} \mathrm{C}$ but lower above $500{ }^{\circ} \mathrm{C}$ compared to concrete with quartz gravel aggregate.

4. The relative bond strength of fibre reinforced concrete (Mix 1 and Mix 2) was lower to $400{ }^{\circ} \mathrm{C}$ but higher to $500{ }^{\circ} \mathrm{C}$ and higher temperatures as in the case of concrete with quartz gravel aggregate.

In Figure 6 are presented the force -slip diagrams for Mix 0 in function of temperature.

The following conclusions can be drawn:

1. With increase of temperature the bond stress decrease and the slip values increases.

2. After temperature loading with $20^{\circ} \mathrm{C}, 50{ }^{\circ} \mathrm{C}$ and $150^{\circ} \mathrm{C}$ the force slip diagrams has the same tendencies. The strength reduction is not more as $20 \%$.

3. After the temperature loading with $600^{\circ} \mathrm{C}$ and $800{ }^{\circ} \mathrm{C}$ the tendencies of force slip diagram change. That could be explain with the missing of chemical bond (decomposition of portlandite). The strength reduction is $80 \%$ after 
temperature loading with $600{ }^{\circ} \mathrm{C}$, and $93 \%$ after temperature loading with 800 ${ }^{\circ} \mathrm{C}$.

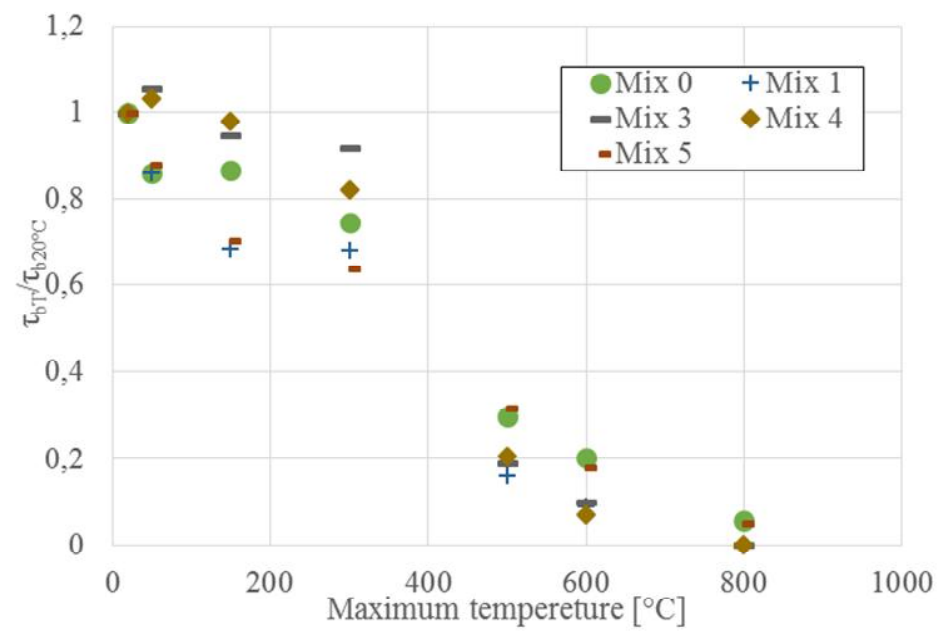

Figure 5: Test result on bond strength measured on ribbed reinforcement (every point gives the average of 3 measurements)

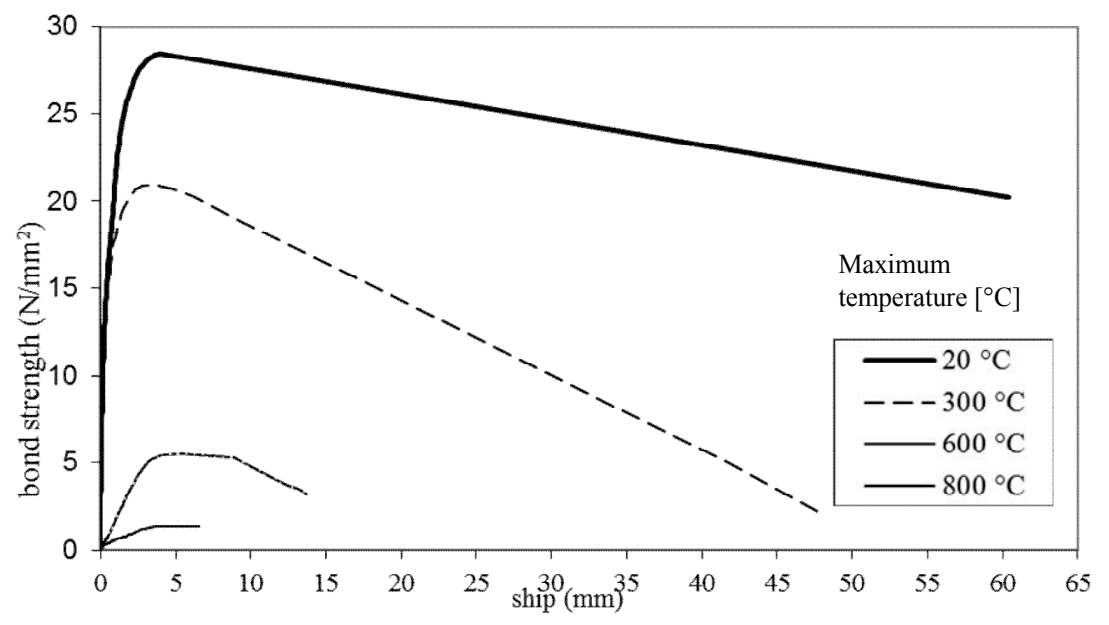

Figure 6: The $\tau_{b^{-}}$slip diagram as a function of temperature (for Mix 0) 


\subsection{Relationship between bond strength and compressive strength}

Figure 7 presents the compressive strength and bond strength of tested concretes with different composition stored at $20^{\circ} \mathrm{C}$ (reinforcement S500, deformed bar, $\mathrm{f}_{\mathrm{yk}}=500$ $\mathrm{N} / \mathrm{mm}^{2}$ ).

According to the figure the following conclusions can be drawn:

(1) The compressive strength of concrete with quartz gravel aggregate and expanded clay aggregate measured at $20^{\circ} \mathrm{C}$ was less than the concrete.

(2) The bond strength in concrete with steel fibers at $20^{\circ} \mathrm{C}$ was higher than the concrete with quartz gravel aggregate without fibres.

(3) The bond strength of concrete with polypropylene fibres and lightweight concrete at $20{ }^{\circ} \mathrm{C}$ is less than the concrete with quartz gravel aggregate without fibres.

Figure 8 indicated the ratio of the bond strength to compressive strength of concrete as a function of the maximum temperature. In the temperature ranges $20^{\circ} \mathrm{C}$ to $400{ }^{\circ} \mathrm{C}$ as well as $500{ }^{\circ} \mathrm{C}$ to $800{ }^{\circ} \mathrm{C}$ the strength ratio decreased approximately linear. Between $400-500$ ${ }^{\circ} \mathrm{C}$ a significant strength reduction took place. The significant strength reduction can be explained by the decomposition of portlandite (at about $450{ }^{\circ} \mathrm{C}$ ).

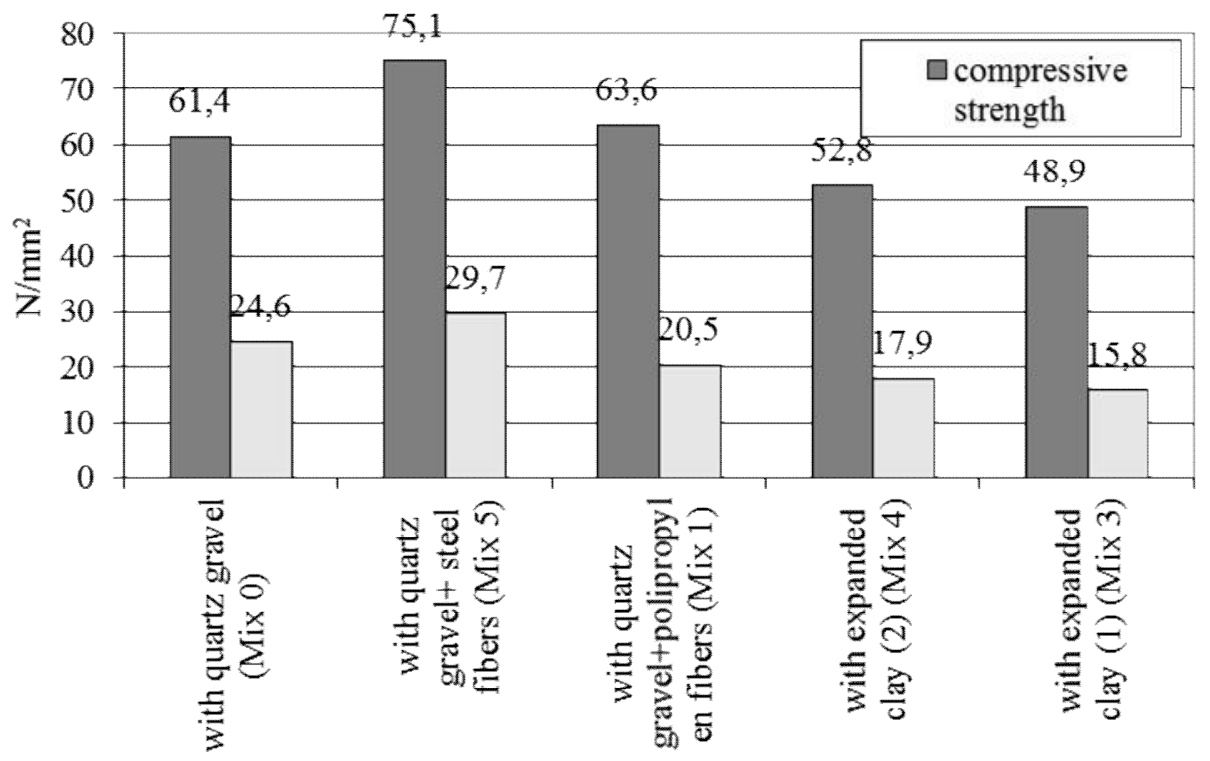

Figure 7: Concrete compressive strength and bond strength with various mixes at $20^{\circ} \mathrm{C}$ 


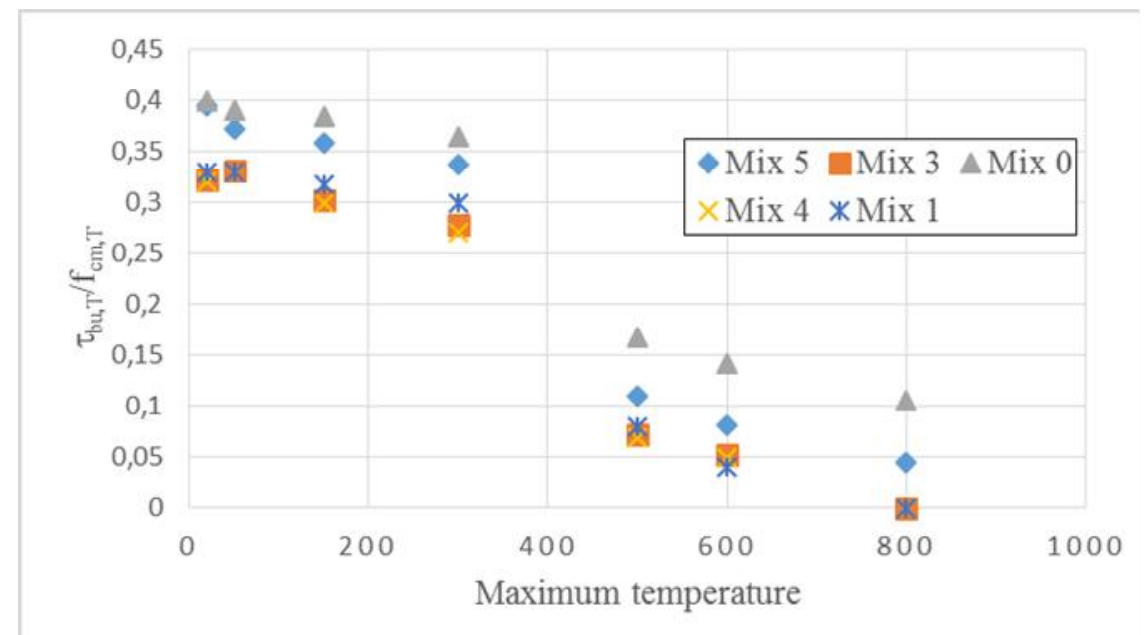

Figure 8: $\tau b u, T / f c m, T$ as a function of maximum temperature in case of ribbed reinforcement

\section{CALCULATION OF BOND STERNGTH VS. TEMPERATURE}

The bond strength in case of concrete with quartz gravel aggregate could be calculated for confined concrete:

$$
\tau_{\mathrm{bmax}}=2.5 \mathrm{f}_{\mathrm{ck}}^{0.5}
$$

Based on test results, a proposal is presented for the modification of MC2010 bond-ship formula as a function of temperature and concrete composition:

For concrete with quartz gravel:

Between

$20{ }^{\circ} \mathrm{C}$ and $400{ }^{\circ} \mathrm{C}$

$400{ }^{\circ} \mathrm{C}$ and $800^{\circ} \mathrm{C}$

$$
\begin{aligned}
\tau_{\text {bmax }, \mathrm{T}} & =2.5 \mathrm{f}_{\mathrm{ck}}{ }^{0.5} \\
\tau_{\mathrm{bmax}, \mathrm{T}} & =\mathrm{fck} 0.4
\end{aligned}
$$

The calculated correlation coefficients were: for $\mathrm{R}^{2}=0.96$ for Mix 0 and $\mathrm{R}^{2}=0.93$ for Mix 5.

For concrete with expanded clay:

Between $\quad 20{ }^{\circ} \mathrm{C}$ and $400{ }^{\circ} \mathrm{C}$

$500{ }^{\circ} \mathrm{C}$ and $700{ }^{\circ} \mathrm{C}$

above $800^{\circ} \mathrm{C}$

$$
\begin{aligned}
\tau_{\mathrm{bmax}, \mathrm{T}} & =2.0 \mathrm{f}_{\mathrm{ck}}{ }^{0.5} \\
\tau_{\mathrm{bmax}, \mathrm{T}} & =\mathrm{fck}^{0.4} \\
\tau_{\mathrm{bmax}, \mathrm{T}} & =0
\end{aligned}
$$

The calculated correlation coefficients were: $\mathrm{R}^{2}=0.98$ for Mix 3 and $\mathrm{R}^{2}=0.98$ for Mix 4 .

\section{CONCLUSIONS}

The following conclusions can be drawn from our experimental study on the influence of high temperatures to the residual bond characteristic. Pull-out specimens tested at cold state after heated up to $\left(20^{\circ} \mathrm{C}, 150{ }^{\circ} \mathrm{C}, 300{ }^{\circ} \mathrm{C}, 400{ }^{\circ} \mathrm{C}, 500{ }^{\circ} \mathrm{C}, 600{ }^{\circ} \mathrm{C}\right.$ and $\left.800{ }^{\circ} \mathrm{C}\right)$. The 
types of concrete were: C, SFRC, PPRC, LWAC1, LWAC2. Type of steel reinforcement was deformed rebar.

Most considerable reduction of bond strength took place between $400^{\circ} \mathrm{C}$ and $500^{\circ} \mathrm{C}$ in all cases. This reduction can be explained by the decomposition of portlandite by $450^{\circ} \mathrm{C}$. This was valid for all tested concrete types (C, SFRC, PPRC, LWAC1, LWAC2) with all tested reinforcements (deformed rebar).

Reduction of bond strength both below $400^{\circ} \mathrm{C}$ and above $500^{\circ} \mathrm{C}$ are close to linear on different levels.

Based on test results, a proposal is presented for the modification of MC2010 bond-ship formula as a function of temperature and concrete composition:

For concrete with quartz gravel:

Between $\quad 20{ }^{\circ} \mathrm{C}$ and $400{ }^{\circ} \mathrm{C}$

$400{ }^{\circ} \mathrm{C}$ and $800{ }^{\circ} \mathrm{C}$

$$
\begin{aligned}
& \tau_{1}=2.5 f_{\text {ck }}{ }^{0.5} \\
& \tau_{1}=f_{\text {ck }}^{0.4}
\end{aligned}
$$

For concrete with expanded clay:

Between $\quad 20^{\circ} \mathrm{C}$ and $400{ }^{\circ} \mathrm{C}$

$500{ }^{\circ} \mathrm{C}$ and $700{ }^{\circ} \mathrm{C}$

above $800^{\circ} \mathrm{C}$

$$
\begin{aligned}
& \tau_{1}=2.0 \mathrm{f}_{\mathrm{ck}}{ }^{0.5} \\
& \tau_{1}=\mathrm{f}_{\mathrm{ck}} 0.4 \\
& \tau^{1}=0
\end{aligned}
$$

\section{REFERENCES}

[1] Kodur R. V., McGrath: Fire endurance of high strength columns, Fire Technol. 89 (2003) 73-87

[2] Khoury G. A.: Effect of fire on concrete and concrete structures, Proc. Struct. Eng. Mater J. 2 (2000) 429-447

[3] Morely P., Royles R.: Response of the bond rein forcing concrete to high temperatures Mag. Concrete Res. 35 (123) (198309 67-74

[4] Haddad, R., Shannis, L.: Post fire behaviour of bond between high strength puzzolanic concrete and reinforcing steel. Consr. Build. Mater 18 (2004) 425-435

[5] Bazant ,Z., Kaplan, M.: Concrete at high temperatures: Material Properties and Mechanical Models. Longman Group Limited, 1996

[6] Reichel ,V.. How fire affects steel-to-concrete bond, Build. Res. pract. 6 (3) (1987)176-187

[7] Diederichs, U., Schneider, U.: Bond strength at high temperatures Mag. Concr. Res. 35 (115)(1978) 75-84

[8] Hertz, K.: The anchorage capacity of reinforcing bars at normal and high temperatures Mag. Concr. Res. 35 (121) (1982) 213-220

[9] Royles, R., Morley, P., Khan, M. R.: The behaviour of reinforced concrete at elevated temperatures with particular reference to bond strength in P. Bartos (Ed) proceedings Conference on Bond in Concrete, Paisley, Scotland, 1982, pp. 217-228

[10] Haddad, R. H., Al-Saleh, R. J., Al-Akhras N. M.: Effect of elevated temperature on bond between reinforced concrete, Fire Safety Journal 43 (2008) 334343

[11]Zhaohui, H.: Modelling the bond between concrete and reinforcing steel in a fire Engineering Structures, Volume 32, Issue 11, November 2010, Pages 3660-3669

[12] fib (2013) Modell Code for concrete structures 2010, Chapter 183-189 